\title{
XIV BAKHTIN CONFERENCE: Bakhtin: Through the Test of Great Time, 04 a 08 de julho de 2011, Universidade de Bolonha, Centro Universitário de Bertinoro (Forli-Cesena), Itália.
}

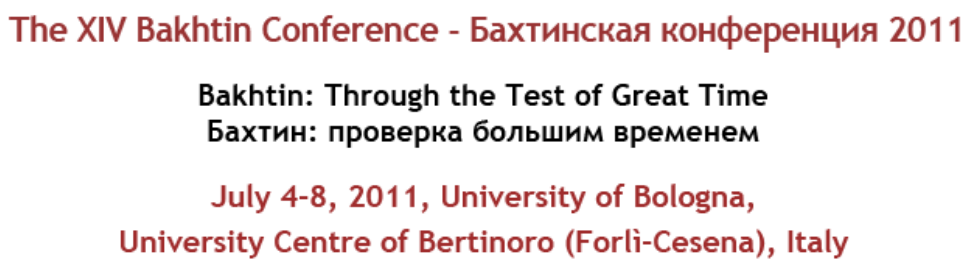

The XIV

A sedução que a teoria bakhtiniana ainda exerce, em pleno século XXI, pode ser comprovada pelo volume de pesquisas e pelo número de pesquisadores que exploram os mais variados aspectos de uma obra que a cada dia apresenta novas possibilidades de interpretação e aplicação.

Desde que se realizou a $1^{\text {a }}$ Conferência Internacional sobre Bakhtin, na Universidade de Queen (Canadá), organizada por Clive Thomson e Anthony Wall, as pesquisas decorrentes das reflexões desse teórico têm se multiplicado. É o que sinalizam as edições subsequentes da Conferência, realizadas sistematicamente a cada quatro anos, em países diferentes, congregando pesquisadores que se debruçam sobre a vida e a obra desse filósofo da linguagem.

A XIV Conferência sobre Bakhtin, realizada na Itália, no período de 04 a 08 de julho, comprovou que o interesse pelo autor continua vivo e que sua teoria tem muito a dizer sobre a cultura moderna. Sob os auspícios da Universidade de Bologna, o Centro Universitário de Bertinoro reuniu pesquisadores de várias partes do mundo que investigam tanto a vida e a obra de Bakhtin quanto as possíveis relações que se estabelecem entre suas reflexões sobre a linguagem e as mais diversas teorias.

\footnotetext{
* Professora da Universidade de Taubaté - UNITAU, Taubaté, São Paulo, Brasil; puzzo@uol.com.br
} 
O tema "Bakhtin: através do Teste do Grande Tempo", proposto para essa Conferência, motivou debates sob vários ângulos, nem sempre convergentes.

As conferências realizadas por pesquisadores russos, ingleses, italianos, americanos, entre outros, evidenciaram os múltiplos enfoques suscitados pelas obras já publicadas e pelas que ainda estão sendo reveladas pela pesquisa do acervo constituído por textos esparsos, como, por exemplo, as cartas e os rascunhos de suas aulas de literatura ministradas em Saransk. Tais publicações permitem relações bastante diversificadas no uso da linguagem, motivando pesquisas e aplicação de sua teoria em campos distintos. O conjunto das palestras apresentadas na XIV Conferência atesta essa tendência de buscar no pensamento do autor relações possíveis, tanto entre pensadores de sua época, como entre pensadores mais recentes.

Entre as conferências a cargo de pesquisadores, como a que leva por título Discussione intorno alla relazione di L. V. Pumpjanskj sul marxismo (1924) e il passaggio di M. M. Bachtin alle opere della seconda metà degli anni venti, ministrada por N. I. Nikolaev, observa-se a tendência de aproximar Bakhtin de autores que de certo modo atuaram na formação do seu pensamento filosófico, como Pumpianski. Segundo Nikolaev, as discussões do círculo de Nevel a respeito das ideias de Pumpianski, que se opunha ao marxismo por considerá-lo cientificamente inconsistente, foi fundamental para a compreensão da obra de Bakhtin na segunda metade dos anos vinte. Como Pumpianski, a partir de 1927' aderiu ao marxismo, considerando-o um experimento, um mal necessário, as obras de Bakhtin da segunda metade do século vinte, de acordo com Nikolaev, seriam uma resposta a Pumpianski, demonstrando uma saída possível ao impasse provocado pela teoria marxista.

Nessa mesma linha comparativa, a conferência Nikolaj e Michail Bachtiny: consonanze e contrappunti. Esperimento di analisi comparata di posizioni filosofiche, de Grigory Tulchinsky, verifica as possibilidades de aproximação e distanciamento entre as posições filosóficas dos irmãos Nicolai e Mikhail Bakhtin. Embora, haja uma diferença radical no destino humano dos dois irmãos, Tulchinsky encontra algo profundamente comum aos dois: ambos receberam uma educação filológica de base, manifestaram grande interesse pela metafísica da ética, exibindo cada um, a seu modo, uma posição filosófica cuja sustentação era a metafísica da liberdade e da responsabilidade. A proposta do autor é a de efetivar uma comparação entre as posições 
filosóficas dos dois irmãos, como um trabalho investigativo interessante capaz de evidenciar uma associação nova e não banal na filosofia russa e talvez mundial do século XX.

Em idêntica linha comparativa, sob o título Gramsci and Bakhtin revisited, Craig Brandist retoma seus artigos escritos há vinte anos sobre a posição crítica de Gramsci e dos membros do Círculo em relação às ideias linguísticas e culturais daquele momento histórico e reavalia-as em função de novas publicações sobre o tema.

Seguindo a mesma orientação comparativa, Cesare Segre, em sua conferência Bachtin e Contini, compara, numa perspectiva historiográfica, a do cronotopo, o percurso, seguido por Contini, de analisar o romance em duas linhas paralelas: a do monologismo e a do plurilinguismo, como o fizera Bakhtin, observando as ligações possíveis entre ambos e aqueles autores por eles referidos.

Numa perspectiva um pouco diferente, Ken Hirschkop, sob o título Urban Irony, procura explorar os conceitos de heteroglossia, ironia e democracia nos centros urbanos, tomando como referência autores que se debruçam sobre essa questão, tais como Simmel, Benjamin e Sennett. Seu objetivo abarca dois momentos: num primeiro, examina os fenômenos descritos por Bakhtin na perspectiva dialógica (estilização, paródia, polêmica interna) como estratégias que tornam a experiência urbana prazerosa e recompensadora. Para o autor, enquanto os textos de Bakhtin, sobre o romance, iniciam a pesquisa sobre a ética cristianizada do romance, esse tema torna-se uma descrição de um modo de interação social que orienta as exigências éticas específicas da vida urbana.

De um ponto de vista mais crítico, em relação à aplicabilidade da teoria de Bakhtin ao romance contemporâneo, o pesquisador canadense Wladimir Krysinski, com Les enjeux dialogiques et monologiques dans l'évolution du roman modern, questiona as categorias de polifonia e dialogismo, de homofonia e monologismo, com as quais Bakhtin analisa as obras de Dostoiévski e Tolstoi, respectivamente. Para Krysinski, tais categorias não são apropriadas para a análise de romances como Ulisses de J. Joyce, Eu, o supremo de Roa Bastos, Ainda uma vez o mar de Arenas, O retorno das caravelas de Lobo Antunes, Paraíso de Sollers, $O$ indizível de Beckett, O Bacharel de René-Louis des Fÿrets, Som e fúria de Faulkner, entre outros. Segundo o autor, as questões dialógicas da evolução do romance demonstram uma transformação do dialogismo. Para 
além de sua posição ética, transforma-se em um monólogo teatral e recitativo. $O$ polimorfismo romanesco, quer dizer, a variabilidade de suas formas, deixa à mostra a constituição dos teatros discursivos pelos quais o dialogismo, nessa nova versão, transcende a perspectiva bakhtiniana. Segundo o autor, as personagens do romance contemporâneo recitam um multilogo, como uma matéria verbal mais complexa que o monólogo do subterrâneo (Dostoiévski). Sob esse aspecto, Krysinski vai além dos conceitos de polifonia e de homofonia cunhando um novo conceito a partir daqueles apontados por Bakhtin.

No conjunto dos trabalhos, evidenciou-se a diversidade de enfoques com que Bakhtin é visto no grande tempo da cultura. Diversidade semelhante pode ser verificada nas comunicações individuais. É preciso destacar a presença de pesquisadores brasileiros, que chamaram a atenção pelo número de participantes, chegando mesmo a provocar questionamentos a respeito do interesse pela teoria de Bakhtin no Brasil. Uma resposta possível seria a abrangência dessa teoria, que pode abrigar pesquisas em várias vertentes, como a teórica, a pedagógica, a comparativa, a analítica, com enfoque para enunciados verbovisuais e literários, como comprovaram as comunicações de pesquisadores brasileiros.

Se, para Krysinski, as categorias de Bakhtin não atendem ao universo da literatura moderna e contemporânea, elas ainda se prestam a múltiplas aplicações, principalmente por tocarem em questões prementes na atualidade, como a responsividade e a responsabilidade tanto de pesquisadores como de enunciadores nas múltiplas esferas de produção, circulação e recepção de enunciados.

Recebido em 26/07/2011

Aprovado em 20/09/2011 